\title{
Full-thickness eye-wall biopsy: long-term results in 9 patients
}

\author{
GHOLAM A. PEYMAN, ClAUdio P. JUAREZ, ANd MOTILAL RAICHAND \\ From the Department of Ophthalmology, University of Illinois Eye and Ear Infirmary, Chicago, USA
}

SUMMARY Nine patients who had an eye-wall biopsy were evaluated for long-term results. The follow-up time ranged from $2 \frac{1}{2} 2$ months to 7 years. Six patients were followed up for more than 2 years. Few operative and postoperative complications were observed. Except for 1 patient with reticulum cell sarcoma, all eyes retained preoperative visual acuity. Tractional retinal detachment occurred only in 1 patient, who had vitreous bands around the biopsy site and did not undergo a simultaneous vitrectomy during the biopsy operation.

Encouraged by the results of eye-wall resection ${ }^{12}$ in the treatment of choroidal melanoma, we conceived the method of eye-wall biopsy to facilitate the study of diseases of the retina and uvea. In 1975 we reported the first studies from our laboratory in experimental eye-wall biopsy. ${ }^{3-6}$ The present report describes the long-term results of eye-wall biopsy in 9 patients.

Correspondence to Dr G. A. Peyman, University of Illinois Hospital Eye and Ear Infirmary, 1855 W Taylor Street, Chicago, IL 60612 , USA.
The follow-up time ranged from $2 \frac{1 / 2}{2}$ months to 7 years (Table 1). Six patients were followed up for more than 2 years.

\section{Materials and methods}

Between 1973 and 1980 a total of 9 patients underwent schlerochorioretinal biopsies (Table 1). Cases 1 and 2 were done to rule out sympathetic ophthalmia. In case 7 the biopsy showed an intraocular reticulum cell

Table 1 Long-term follow-up data on 9 patients after eye-wall biopsy

\begin{tabular}{|c|c|c|c|c|c|c|c|}
\hline \multirow{2}{*}{$\begin{array}{l}\text { Case } \\
\text { no. }\end{array}$} & \multirow{2}{*}{$\begin{array}{l}\text { Age }(y r), \\
\text { race, sex }\end{array}$} & \multirow{2}{*}{ Diagnosis before surgery } & \multirow{2}{*}{$\begin{array}{l}\text { Follow-up } \\
\text { period }\end{array}$} & \multirow{2}{*}{$\begin{array}{l}\text { Status of eye prior to } \\
\text { surgery-biopsy }\end{array}$} & \multirow{2}{*}{$\begin{array}{l}\text { Anatomical } \\
\text { success }\end{array}$} & \multicolumn{2}{|l|}{ Visual results } \\
\hline & & & & & & Before surgery & After surgery \\
\hline 1 & $\begin{array}{l}22 \\
\mathbf{W} / \mathbf{M}\end{array}$ & $\begin{array}{l}\text { Retained intraocular } \\
\text { foreign body; chalcosis; } \\
\text { bilateral chorioretinitis of } \\
\text { unknown aetiology }\end{array}$ & $7 \mathrm{yr}$ & $\begin{array}{l}\text { Traction retinal detachment } \\
\text { inferior temporal quadrant } \\
\text { (left eye) }\end{array}$ & Yes & Light perception & $\begin{array}{l}\text { Light perception } \\
\text { for } 6 \text { mo, then } \\
\text { no light } \\
\text { perception }\end{array}$ \\
\hline 2 & $\begin{array}{l}54 \\
\mathbf{W} / \mathbf{M}\end{array}$ & $\begin{array}{l}\text { Phthisis bulbi, right eye; } \\
\text { uveitis, left eye, for } 4 \text { years. } \\
\text { Trauma, right eye } 4 \text { years } \\
\text { previously }\end{array}$ & $6 \mathrm{yr}$ & Phthisis bulbi (right eye) & Unknown & $\begin{array}{l}\text { No light } \\
\text { perception }\end{array}$ & $\begin{array}{l}\text { No light } \\
\text { perception }\end{array}$ \\
\hline 3 & $\begin{array}{l}22 \\
B / F\end{array}$ & $\begin{array}{l}\text { Retinitis-pigmentosa-like } \\
\text { syndrome. Leber's } \\
\text { amaurosis congenita }\end{array}$ & $2 \frac{1}{2} \mathrm{mo}$ & $\begin{array}{l}\text { Pendular nystagmus, bone } \\
\text { spicules, attentuated vessels } \\
\text { (right eye) }\end{array}$ & Yes & Light perception & Light perception \\
\hline 4 & $\begin{array}{l}22 \\
\mathrm{~B} / \mathrm{F}\end{array}$ & $\begin{array}{l}\text { Retinitis-pigmentosa-like } \\
\text { syndrome }\end{array}$ & $8 \mathrm{mo}$ & $\begin{array}{l}3+\text { bone spicules, attenuated } \\
\text { vessels (left eye) }\end{array}$ & Yes & $4 \mathrm{ft} / 200$ & $4 \mathrm{ft} / 200$ \\
\hline 5 & $\begin{array}{l}27 \\
B / F\end{array}$ & $\begin{array}{l}\text { Favre-Goldmann } \\
\text { syndrome }\end{array}$ & $14 \mathrm{mo}$ & $\begin{array}{l}\text { Atypical retinitis pigmentosa, } \\
\text { peripheral retinoschisis } \\
\text { (right eye) }\end{array}$ & Yes & Hand motions & Hand motions \\
\hline 6 & $\begin{array}{l}23 \\
B / F\end{array}$ & $\begin{array}{l}\text { Chorioretinal degeneration } \\
\text { of unknown aetiology }\end{array}$ & $5 \mathrm{yr}$ & $\begin{array}{l}\text { Atypical retinitis pigmentosa, } \\
\text { macular hole }\end{array}$ & Yes & $20 / 200$ & $20 / 200$ \\
\hline 7 & $\begin{array}{l}58 \\
W / F\end{array}$ & $\begin{array}{l}\text { Chorioretinitis or } \\
\text { intraocular reticulum cell } \\
\text { sarcoma }\end{array}$ & $2 \mathrm{yr}$ & $\begin{array}{l}\text { Marked vitreous haze, vitreous, } \\
\text { retinal, and subretinal tumors } \\
\text { (right eye) }\end{array}$ & Yes & Light perception & $\begin{array}{l}\text { Light perception } \\
\text { for } 20 \mathrm{mo} \text {, then } \\
\text { no light } \\
\text { perception }\end{array}$ \\
\hline 8 & $\begin{array}{l}35 \\
\mathbf{W} / M\end{array}$ & $\begin{array}{l}\text { Retinitis-pigmentosa-like } \\
\text { syndrome }\end{array}$ & $4 \mathrm{yr}$ & $\begin{array}{l}\text { Retina attached: } 3+\text { bone } \\
\text { spicules }\end{array}$ & Yes & Hand motions & Hand motions \\
\hline 9 & $\begin{array}{l}28 \\
W / M\end{array}$ & $\begin{array}{l}\text { Retinitis-pigmentosa-like } \\
\text { syndrome }\end{array}$ & $3 y r$ & $\begin{array}{l}\text { Retina attached: } 3+\text { bone } \\
\text { spicules }\end{array}$ & Yes & Hand motions & Hand motions \\
\hline
\end{tabular}

$B=$ black. $F=$ female $. M=$ male. $W=$ white, $4 \mathrm{ft}=120 \mathrm{~cm}$. 
sarcoma. The remaining cases had retinitispigmentosa-like syndromes. Three patients were lost to follow-up (cases 3,4 , and 5) at $2 \frac{1}{2}, 8$, and 14 months, respectively.

Of the 9 biopsies 7 were performed at the University of Illinois Eye and Ear Infirmary and 2 at the Erskin Hospital in Madurai, India. All procedures were performed by one surgeon (G.A.P.). Patients selected for surgery were told in detail about the procedure, including its nontherapeutic and experimental features. Operations performed in the United States were approved by the Committee of Associates on Human Experimentation.

All patients had complete, extensive medical and ophthalmological examinations preoperatively. The
2 patients operated on in India were given local anaesthesia; those in the United States had general anaesthesia.

\section{SURGICAL TECHNIQUE}

A $360^{\circ}$ peritomy was performed, and the rectus muscles were isolated with 4-0 silk sutures. A Peyman eye basket (Fig. 1A), $12 \mathrm{~mm}$ in diameter, was sutured to the sclera (Fig. 1B). An $8 \mathrm{~mm}$ trephine (Fig. 1C) was used to demarcate approximately half the thickness of the sclera. The sclera was then dissected (Fig. 1D) with a No. 64 Beaver blade. A partialthickness disciform scleral button was removed and stored in saline solution containing $200 \mu \mathrm{g} / \mathrm{ml}$ of gentamicin. A $4 \mathrm{~mm}$ trephine was used to demarcate
Fig. 1 A: Peyman eye basket, 12 $\mathrm{mm}$ in diameter. B: Eye basket sutured to sclera. C: Half thickness of sclera demarcated on 2/3 of its thickness by an $8 \mathrm{~mm}$ trephine. D: Sclera is dissected with a no. 64 Beaver blade. E: Sclera is further demarcated with a $4 \mathrm{~mm}$ trephine. F: Diathermy is applied. G: Biopsy is removed with corneoscleral scissors. H: Vitrectomy performed through biopsy site. I: $8 \mathrm{~mm}$ partial-thickness sclera is sutured back in its place. J: Injection of air to reestablish the intraocular pressure.

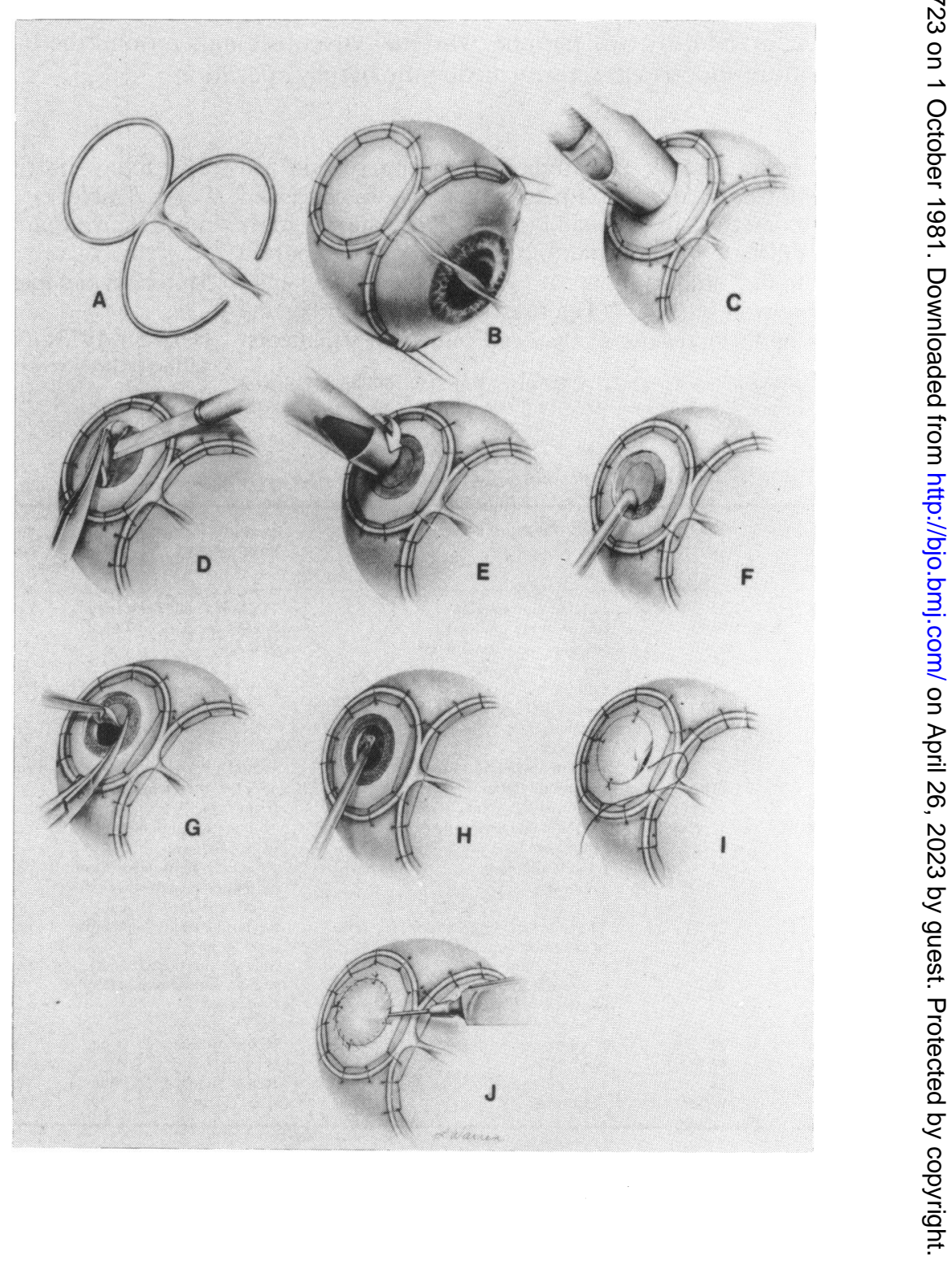


Fig. 2 A sclerochorioretinal biopsy from patient with clinically diagnosed Leber's amaurosis congenita. Top: Fundus photograph 1 month postoperatively. Arrows indicate resected area surrounded by chorioretinal scarring. Note clarity of the media. Middle: Low-power view of the sclera $(S)$, choroid $(C)$, and retina $(R)$. (Haematoxylin and eosin, $\times 15)$. Bottom: Higher power demonstrating atropic retina (Ret) with loss of photoreceptor outer segments, sparse outer nuclear layer, and loss of ganglion cells. Chor indicates choroid; Br, Bruch's membrane. (Mallorybluestain, $\times 150$ ).

an area within the partially dissected $8 \mathrm{~mm}$ area (Fig. 1E). After surface and penetrating diathermy (Fig. $1 F)$ the sclera, choroid, and retina were then penetrated through the margin of the $4 \mathrm{~mm}$ button with a No. 52 Beaver blade. The section was completed with curved corneoscleral scissors (Fig. 1G). All patients except case 3 had a vitrectomy through the biopsy site with the vitrophage (Fig. 1H). After vitrectomy the resected area was covered with the $8 \mathrm{~mm}$ partialthickness sclera; 4 interrupted sutures were applied and a 9-0 running nylon suture was added (Fig. 1I). The intraocular pressure was re-established with an injection of air through the graft edge of a 30-gauge cannula (Fig. 1J).

\section{Results}

During the surgical procedure minor choroidal bleeding occurred in 4 patients. The choroidal bleeding originated from the biopsy site and was easily controlled with diathermy (Table 1). Early postoperative vitreous haemorrhage that occurred in one eye cleared within 3 weeks. Also in the early postoperative period 1 patient (case 3, Table 1) developed thick vitreoretinal traction bands around the biopsy site that progressed to a tractional retinal detachment. This patient did not have a vitrectomy procedure during the biopsy operation. The patient's visual acuity remained unchanged, and it was thought that additional surgery to reattach the retina would not improve the vision. All patients operated on after this underwent subtotal vitrectomy through the biopsy site.

After surgery all eyes were inflamed for a period of 2 weeks. By slit-lamp examination the anterior chamber showed 2 to $3+$ cells on the first postoperative day. By 1 to 2 weeks later there was only trace flare in the anterior chamber. No patient complained of pain or unusual discomfort. Within 2 weeks of surgery the ocular media were clear and a chorioretinal scar was visible (Fig. 2, top). Only 1 patient (case 7, Table 1) did not retain preoperative visual acuity. This patient had bilateral reticulum cell sarcoma. After 2 months the destruction of the patient's retina by tumour cells resulted in a visual acuity of no light perception bilaterally. One patient
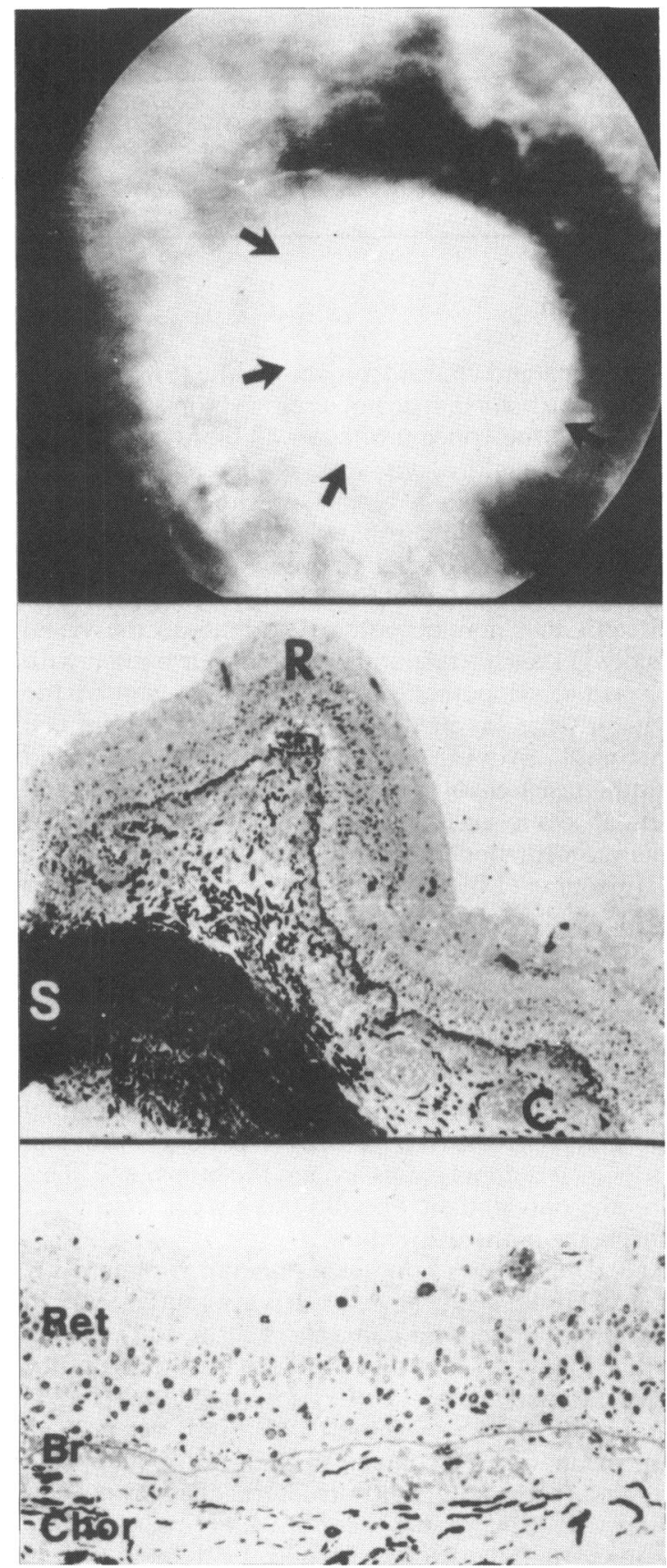

developed minimal posterior subcapsular cataract in the late postoperative period. Although small, the biopsy specimens showed intact sclera, choroid, and retina (Fig. 2, middle). The cellular structures were well preserved for light and electron microscopy (Fig. 2 , bottom). 
Table 2 Surgical and early and late postoperative complications

\begin{tabular}{ll}
\hline Surgical & $\begin{array}{l}\text { Choroidal bleeding, 4 patients (bleeding from biopsy } \\
\text { site, easily controlled by diathem,y) }\end{array}$ \\
Early postoperative & $\begin{array}{l}\text { Vitreous haemorrhage, 1 patient (cleared in 3 weeks) } \\
\text { Vitreous traction on biopsy site, 1 patient }\end{array}$ \\
$\begin{array}{l}\text { (14 days) } \\
\text { Late postoperative } \\
\text { (14 days) }\end{array}$ & \begin{tabular}{l} 
Minimal posterior subcapsular cataract, 1 patient \\
\hline
\end{tabular} \\
\hline
\end{tabular}

\section{Discussion}

The retina and choroid are among the few tissues in the human body that do not undergo biopsy routinely. Although the concept of eye-wall biopsy is unthinkable in a healthy eye, with proper technique it is possible to obtain a biopsy specimen of diseased retina and choroid without significant complication.

The purpose and value of eye-wall biopsy is 2-fold. It is helpful diagnostically to identify unknown ocular diseases that may be potential threats to the visual acuity in the contralateral eye (as in our patient with suspected sympathetic ophthalmia) or even to the patient's life (as in our patient with reticulum cell sarcoma). Eye-wall biopsy is also useful to expand future research into diseases for which uveal and retinal tissue has not been readily available for analysis with modern laboratory tests.

Encouraged by the results and few complications after extensive laboratory study, we evaluated this technique in patients with substantial retinal disease and reduced visual acuity of less than 20/200. We observed only few operative and postoperative complications. Except in 1 patient with reticulum cell sarcoma all eyes retained preoperative visual acuity. Significant complications, such as tractional retinal detachment, occurred in only 1 patient, who had vitreous tractional bands around the biopsy site. This was the only patient who did not have a vitrectomy during the biopsy procedure.

Recent studies on experimental animals by Constable and colleagues ${ }^{7}$ were also successful. In addition they reported on a short-term study in man with a follow-up period of a few days. ${ }^{8}$ Although they used a similar technique, they advocated the removal of smaller pieces of tissue $(1 \times 1.5 \mathrm{~mm}$ versus $4 \times 4$ $\mathrm{mm}$ ) than we do. Constable et al., however, reported common morphologically structural changes in their biopsy specimens that we have not observed. We believe that these changes may be related to the handling of the small specimens during removal. A larger sized tissue can be better handled and can be divided in half-for example, one part for electron microscopy and the other for histochemical or biochemical study. If an infective agent is suspected, one part can be cultured for virus, bacteria, or fungus. They also suggested that a vitrectomy is unnecessary during the biopsy. We prefer to perform a vitrectomy during the procedure to prevent the formation of scaffolding for future tissue ingrowth and resultant vitreous traction at the biopsy site.

Transvitreal eye-wall biopsy has also been tried successfully by other investigators in experiments with rabbits. ${ }^{9}$ This technique has not been used in man yet.

Eye-wall biopsy is not a routine surgical intervention, and we believe it should be performed only by experienced vitreoretinal surgeons who have had previous experience with this technique on experimental animals. Proper explanation detailing the experimental nature of the operation should be given to, and informed consent obtained from, the patient before the surgery is performed. On removal the tissues should be handled with extreme care. A highly skilled technician or one familiar with laboratory techniques should be in the operating room to receive the tissue at the time of removal and process it accordingly.

We feel that this procedure can be useful in the diagnosis of unusual ophthalmologic diseases in which the visual acuity is already compromised or the contralateral eye is in danger of being affected by a similar disease process. It may also be used when permanent visual loss is suspected from an unknown disease state and when enucleation would otherwise be recommended for diagnostic or therapeutic measurement.

This work was supported in part by core grant IP 30EY01792 from the National Institutes of Health. Bethesda. Md

\section{References}

1 Peyman GA, Dodich WA. Full thickness eyewall resection: An experimental approach for treatment of choroidal melanoma: $I$. Dacron graft. Invest Ophthalmol Visual Sci 1972; 11: 115-21.

2 Peyman GA. Raichand M. Full thickness eyewall resection of choroidal neoplasms. Ophthalmology 1979; 86: 1024-36.

3 Peyman GA. Meisels HI, Batko HA, et al. Full thickness eye-wall biopsy: I. An experimental approach to the tissue diagnosis and study of choroidal and retinal lesions. Invest Ophthalmol Visual Sci $1975 ; 14: 484-7$.

4 Peyman GA. Homer P. Kasbeer R. Vlchek J. Full thickness eyewall biopsy: II. In primates. Invest Ophthalmol Visual Sci 1975 ; 14: $565-7$.

5 Peyman GA, Fishman GA. Sanders DR, et al. Biopsy of human sclerochorioretinal tissue. Invest Ophthalmol Visual Sci 1975; 14: 707-10.

6 Peyman GA. Fishman GA. Sanders DR, et al. Histopathology of Goldmann-Favre syndrome obtained by full thickness eyewall biopsy. Ann Ophthalmol 1975; 9: 479-84.

7 Constable IJ, Slatter DH, Horne R. Chorioretinal biopsy in dogs. Invest Ophthalmol Visual Sci 1980; 19: 603-9.

8 Constable IJ, Chester GH, Horne R, et al. Human chorioretinal biopsy under controlled systemic hypotensive anaesthesia. $\mathrm{Br} J$ Ophthalmol 1980; 64: 559-64.

9 Griffin JR, Straastsma BR, Kreiger AE. Transvitreal chorioretinal biopsy in the rabbit. Am J Ophthalmol 1975; 79: 25-38. 